\title{
Utilization of Mixture of Teak Wood Sawdust and Bagasse Fiber using Treatment of Fiber Variations and Alkali NaOH Immersion as A Refrigerator Insulation Material
}

\author{
Alam Baheramsyah ${ }^{1}$, Ede Mehta Wardhana ${ }^{2}$, Achmad Taufik Rendi Kisserah ${ }^{3}$ \\ (Received: 03 February 2019 / Revised: 01 June 2019 / Accepted: 28 September 2019)
}

\begin{abstract}
Tectona grandis L.f.) and previously immersed bagasse fiber (Saccharum officinarum) into an alkali $\mathrm{NaOH}$ solution to improve the mechanical properties of the fiber and reduce the value of material thermal conductivity. The most optimal test and analysis results were obtained by composing $50 \%$ teak wood sawdust with $50 \%$ of previously immersed bagasse fiber in an alkali $\mathrm{NaOH}$ solution at a level of $15 \%$. The obtained conductivity value is $0.2907 \mathrm{~W} / \mathrm{mK}$, the density is $0.4901 \mathrm{gram} / \mathrm{cm} 3$. Experiments on changes in temperature of ice, fish, and coolbox chamber as well as experiments on the duration of fish preservation in the coolbox with variations in the composition of straight fibers have better performance compared to the variation of random fiber which is able to preserve fish for 34 hours with minimum temperature of $0,2^{\circ} \mathrm{C}$. For fishing duration of two days, coolbox with a variety of straight fiber has almost the same performance as coolbox made from styrofoam and has the potential to replace styrofoam because it is more environmentally friendly.
\end{abstract}

Keywords - alkali $\mathrm{NaOH}$, coolbox, insulation, thermal conductivity, styrofoam.

\section{INTRODUCTION}

$\mathrm{T}_{\mathrm{he}}$ type of coolbox that commonly used by fishermen is a coolbox made of Styrofoam. Styrofoam has disadvantages such as being dangerous both for human health and the environment, thus it needs an effort to reduce the use of Styrofoam. Styrofoam can be replaced with material that has properties as an insulator and low thermal conductivity [1]. Teak wood sawdust (Tectona grandis L.f.) and bagasse fiber (Saccharum officinarum) are natural materials which have low thermal conductivity values between $0.022 \mathrm{~W} / \mathrm{mK}$ to $0.082 \mathrm{~W} / \mathrm{mK}$ [2-9].

Bagasse fiber is insoluble in water and consists mainly of cellulose $37.65 \%$, pentosan $27.97 \%$, and lignin $22.09 \%$. Lignin $\left(\mathrm{C}_{9} \mathrm{H}_{10} \mathrm{O}_{2}\left(\mathrm{OCH}_{3}\right) \mathrm{n}\right)$ is one of the constituent components of plants which is insoluble in water and stable in nature but useful as an adhesive that connects cellulose to hemicellulose [10]. While cellulose is a polysaccharide with chemical formulas similar to starch $\left(\mathrm{C}_{6} \mathrm{H}_{10} \mathrm{O}_{5}\right)_{\mathrm{n}}$ it is not easily soluble in air and is not easily degraded either chemically or mechanically. [2-7]. Natural fibers have hydrophilic properties, resulting in a

Alam Baheramsyah, Department of Marine Engineering, Institut Teknologi Sepuluh Nopember, Surabaya 60111, Indonesia, Email : abaheramsyah@gmail.com

Ede Mehta Wardhana, Department of Marine Engineering, Institut Teknologi Sepuluh Nopember, Surabaya 60111, Indonesia, Email : edewardhana123@gmail.com

Achmad Taufik Rendi Kisserah, Department of Marine Engineering, Institut Teknologi Sepuluh Nopember, Surabaya 60111, Indonesia, Email : taufikrendikisserah@gmail.com low value of adhesion force between fiber and matrix. To optimize cellulose properties and increase the adhesion force between fibers and polymers, both physical and chemical treatments are needed.

Chemical treatment of fibers can change the physical and chemical structure of the fiber surface. One of the chemical treatment processes is alkalization which is the most widely used method for removing the content of lignin and oil that covers the outer surface of the fiber. The impact caused by doing alkalization treatment is the change in hydrogen bonds in the structure of the fiber tissue which changes the surface of the fiber becoming rough. thus, it can reduce the value of thermal conductivity in natural fibers [8-14]. In this research, the alkalization process was carried out by immersing the fiber in an alkali $\mathrm{NaOH}$. $\mathrm{NaOH}$ is chosen because it is widely used on the industrial scale is given relatively lower in price and is a strong base solution classified as easily soluble in water that can be perfectly ionized. The chemical reaction that occurs during the process of soaking the fiber using an alkali $\mathrm{NaOH}$ solution is shown in figure 1.

Lignin reacts with a solution of $\mathrm{NaOH}$ which dissociates into $\mathrm{Na}^{+}$and $\mathrm{OH}^{-}$. $\mathrm{OH}^{-}$ion reacts with an $\mathrm{H}$ group on lignin and then forms $\mathrm{H}_{2} \mathrm{O}$. This causes the $\mathrm{O}$ group to become free radicals and reactive to $\mathrm{C}$ then form an epoxy ring $(\mathrm{C}-\mathrm{O}-\mathrm{C})$ resulting in a series of groups releasing bonds to group $\mathrm{O}$ and producing two separate benzene rings. Both benzene rings each have an $\mathrm{O}$ group that is reactive and reacts with $\mathrm{Na}^{+}$and then dissolves in a base solution so that the lignin disappears when rinsed and the fiber diameter decreases [15-18]. 

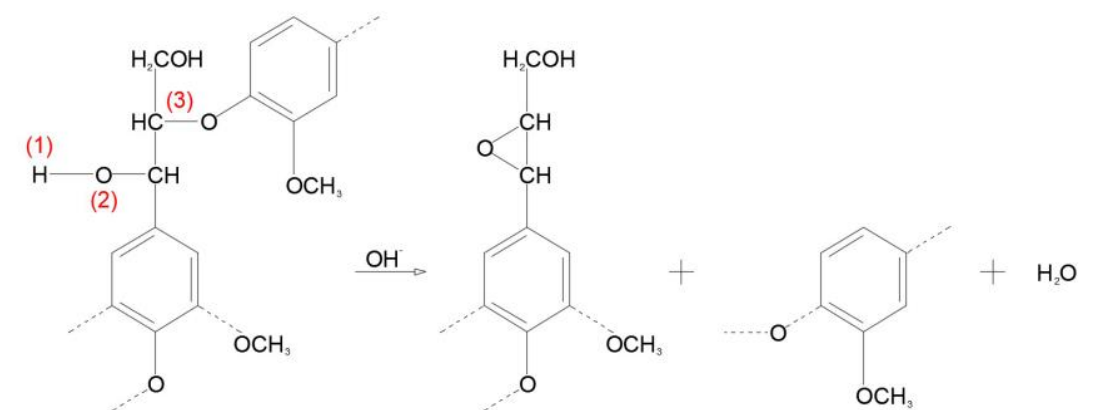

Figure. 1. The Chemical Reaction During the Process of Soaking the Fiber Using An Alkali $\mathrm{NaOH}$

\section{METHOD}

\section{A. Specimen Making}

The making of specimens is carried out using a mixture of teak wood sawdust (Tectona grandis L.f.) with bagasse fiber (Saccharum officinarum). The purpose of making these specimens is to determine the value of the thermal conductivity of the material and the density of the material. Before the specimen is made, bagasse fiber is given a chemical treatment by immersing it into an alkali $\mathrm{NaOH}$ solution which then is mixed with polyurethane adhesive. The specimens are formed according to the mold made of PVC pipe with a diameter of $3.8 \mathrm{~cm}$ and a height of $5 \mathrm{~cm}$. While making an alkali solution is done by reacting the distilled water solution with $\mathrm{NaOH}$ solids according to the variation of the level of $0 \%$ (without soaking an alkali $\mathrm{NaOH}$ solution), $15 \%$, and $30 \%$. There are nine specimens that are being tested for the value of thermal conductivity and density for each variation of the fiber arrangement with the same chemical composition and consist of nine specimens of variations in random fiber arrangement, and nine specimens of variations in straight fiber arrangement. However, this research does not cover the test of nine specimens of variations in the straight fiber arrangement due to manufacturing difficulties and less supportive test equipment (specimens were difficult to make). To continue research on variations of straight fibers arrangement, researchers directly compared the performance of the test results with random fibers when making a prototype or coolbox model without testing thermal conductivity and mass type specimens.

The composition of nine specimens with variations in the random fiber arrangement to be tested are as follow:

1. Specimen $1=70$ grams of teak wood sawdust: 30 grams of bagasse fiber without soaking $\mathrm{NaOH}(0 \%)$

2. Specimen $2=70$ grams of teak wood sawdust: 30 grams of bagasse fiber with soaking $\mathrm{NaOH}(15 \%)$

3. Specimen $3=70$ grams of teak wood sawdust: 30 grams of bagasse fiber with soaking $\mathrm{NaOH}(30 \%)$

4. Specimen $4=50$ grams of teak wood sawdust: 50 grams of bagasse fiber without soaking $\mathrm{NaOH}(0 \%)$

5. Specimen $5=50$ grams of teak wood sawdust: 50 grams of bagasse fiber with soaking $\mathrm{NaOH}(15 \%)$
6. Specimen $6=50$ grams of teak wood sawdust: 50 grams of bagasse fiber with soaking $\mathrm{NaOH}(30 \%)$

7. Specimen $7=70$ grams of teak wood sawdust: 30 grams of bagasse fiber without soaking $\mathrm{NaOH}(0 \%)$

8. Specimen $8=70$ grams of teak wood sawdust: 30 grams of bagasse fiber with soaking $\mathrm{NaOH}(15 \%)$

9. Specimen $9=70$ grams of teak wood sawdust: 30 grams of bagasse fiber with soaking $\mathrm{NaOH}(30 \%)$

\section{B. Specimen Testing}

1. Density Test

The equation to calculate the density of an object is :

$$
\rho=\frac{m}{V}
$$

Where $: \rho=$ density $\left(\mathrm{gr} / \mathrm{cm}^{3}\right)$

$$
\begin{aligned}
& \mathrm{m}=\text { mass of specimen }(\mathrm{gr}) \\
& \mathrm{V}=\text { volume of specimen }\left(\mathrm{cm}^{3}\right)
\end{aligned}
$$

The tested specimens have cylindrical shape thus, the volume value can be calculated by multiplying the crosssectional area of the specimen in a circle with a high specimen. The mass of specimens can be known by weighing using digital scales.

\section{Thermal Conductivity Test}

Testing of thermal conductivity in this study uses the ASTM E1225 standard. The specimen is tested by placing it between two copper metal pieces. To find out the temperature of the specimen points, a thermocouple is installed. After obtaining temperature data, the calculation is then carried out with the following steps:

a. Copper Average Temperature Calculation

$$
\mathrm{Tc}_{\mathrm{avg}}=\frac{T_{1+T_{2}}}{2}
$$

Where:

$$
\begin{array}{ll}
\mathrm{T}_{\text {AVG copper }} & =\text { Average copper temperature }(\mathrm{K}) \\
\mathrm{T} 1 & =\text { Temperature } 1(\mathrm{~K}) \\
\mathrm{T} 2 & =\text { Temperature } 2(\mathrm{~K})
\end{array}
$$

\section{b. Copper Thermal Conductivity Calculation}

The value of copper thermal conductivity can be calculated using the interpolation method in the thermal characteristics table of some solid metals or better known as table A-1 (table 1).

TABLE 1

THERMAL CONDUCTIVITY OF COOPER

\begin{tabular}{cccc}
\hline Material & \multicolumn{3}{c}{ Thermal Conductivity $(\mathbf{W} / \mathbf{m K})$} \\
\hline & $300 \mathrm{~K}$ & $400 \mathrm{~K}$ & $500 \mathrm{~K}$ \\
\hline Pure Cooper & 401 & 393 & 388
\end{tabular}


c. Heat Value Calculation

The heat value of copper can be calculated using the equation (3)

$$
Q_{c}=\frac{c \times A_{c} \times \Delta T_{c}}{L_{e}}
$$

Where :

$Q_{\mathrm{c}}=$ Heat in Cooper $(\mathrm{W})$

$\mathrm{K}_{\mathrm{c}} \quad$ = Thermal Conductivity of copper $(\mathrm{W} / \mathrm{mK})$

$\mathrm{A}_{\mathrm{c}}=$ Area of Cooper Surface $\left(\mathrm{m}^{2}\right)$

$\Delta T c=$ Temperature differences $\left({ }^{\circ} \mathrm{C}\right)$

$\mathrm{L}_{\mathrm{c}} \quad=$ Length of copper $(\mathrm{m})$

In this experiment, the amount of incoming heat (heat in copper) is assumed to be equal to the amount of heat that comes out (heat on the specimen).

$$
\begin{gathered}
Q_{\text {in }}=Q_{\text {out }} \\
Q_{\text {cooper }}=Q_{\text {specimen }}
\end{gathered}
$$

\section{d. Thermal Conductivity Calculation}

The amount of incoming heat $(\mathrm{Qc})$ is calculated by equation (3) and the thermal conductivity of the specimen is calculated by equation (4).

$$
K_{s p}=\frac{Q_{s p} \times L_{s p}}{A_{s p} \times \Delta T_{s p}}
$$

Where :

$Q_{\text {sp }} \quad=$ Heat in Cooper (W)

$\mathrm{K}_{\mathrm{sp}} \quad=$ Thermal Conductivity of the specimen $(\mathrm{W} / \mathrm{mK})$

$\mathrm{A}_{\mathrm{sp}} \quad=$ Area of Specimen Surface $\left(\mathrm{m}^{2}\right)$

$\Delta T_{\mathrm{sp}}=$ Temperature differences $\left({ }^{\circ} \mathrm{C}\right)$

$\mathrm{L}_{\mathrm{sp}} \quad=$ Length of specimen $(\mathrm{m})$

C. Specimen Selection

Specimen selection is done by giving ranks, scores, and weights. The percentage of the greatest value from the weighting results is used as a reference for making the coolbox. In this research, the fifth specimen has the highest final value. Thus, the manufacture of coolboxes with a variation of a random straight and random fiber is using the reference of the fifth specimen which has a composition of 50 grams of teak wood sawdust: 50 grams of previously immersed bagasse fiber in $15 \%$ of $\mathrm{NaOH}$ solution.

\section{Coolbox Making}

After selecting the specimen with the highest percentage value, then it is used as a recommendation for making a prototype of coolbox with the following dimensions:

Length : $33,5 \mathrm{~cm}$

Width $: 24,5 \mathrm{~cm}$

Height : $27 \mathrm{~cm}$

The specification of coolbox can be seen in table 2 .

\section{E. Full-Scale Experiment}

The experiment is conducted by comparing the performance of the cool box with the selected composition for random fiber and straight fiber arrangement and cool box made of Styrofoam. The three Coolboxes will be treated the same as given by layers of plywood and resin. The experiment was carried out by inserting tuna with a mass of 500 grams and $2.5 \mathrm{~kg}$ of ice into the coolbox.

\section{a. Cooling Time}

The cooling time observed is the duration of the coolbox containing fish and wet ice reaches a temperature of $20^{\circ} \mathrm{C}$.

b. The Lowest Temperature Achieved by Each Coolbox

The observation scoop was the lowest temperature value achieved by the cool box within 24 hours with the time span of data collection every 30 minutes. The observation was carried out by observing the temperature at a number of conservation points, namely the first point below the wet ice surface, the second point in the fish body, and the third point in the space inside the cool box. In addition to these three points, data of surrounding temperature is also taken every 30 minutes.

\section{RESULT AND DISCUSSION}

\section{A. Chemical Fiber Treatment and Test Result \\ a. Chemical Fiber Treatment Result}

The difference between the three fibers both physically and chemically can be observed virtually as shown in figure 6. Physically, there is a difference between the color and shape of the fiber. Fiber that has been soaked using 15\% $\mathrm{NaOH}$ and $30 \% \mathrm{NaOH}$ has a darker color, has a more regular shape, and has a smaller diameter than fiber without any immersion process.

\section{b. Density Test Result}

Based on table 3, the variation of random structures with a composition of $30 \%$ teak wood sawdust and $70 \%$ bagasse fiber has a mass value and volume ranging from 26.3 grams to 26.9 grams and the volume ranging from $55.16 \mathrm{~cm} 3$ to $58.13 \mathrm{~cm} 3$. The density for the specimens in this composition ranges from $0.48 \mathrm{~g} / \mathrm{cm} 3$ to $0.50 \mathrm{~g} /$ $\mathrm{cm} 3$ where the 9th specimen has the smallest density value. 
International Journal of Marine Engineering Innovation and Research, Vol. 4(2), Sept. 2019. 78-86 (pISSN: 2541-5972, eISSN: 2548-1479)

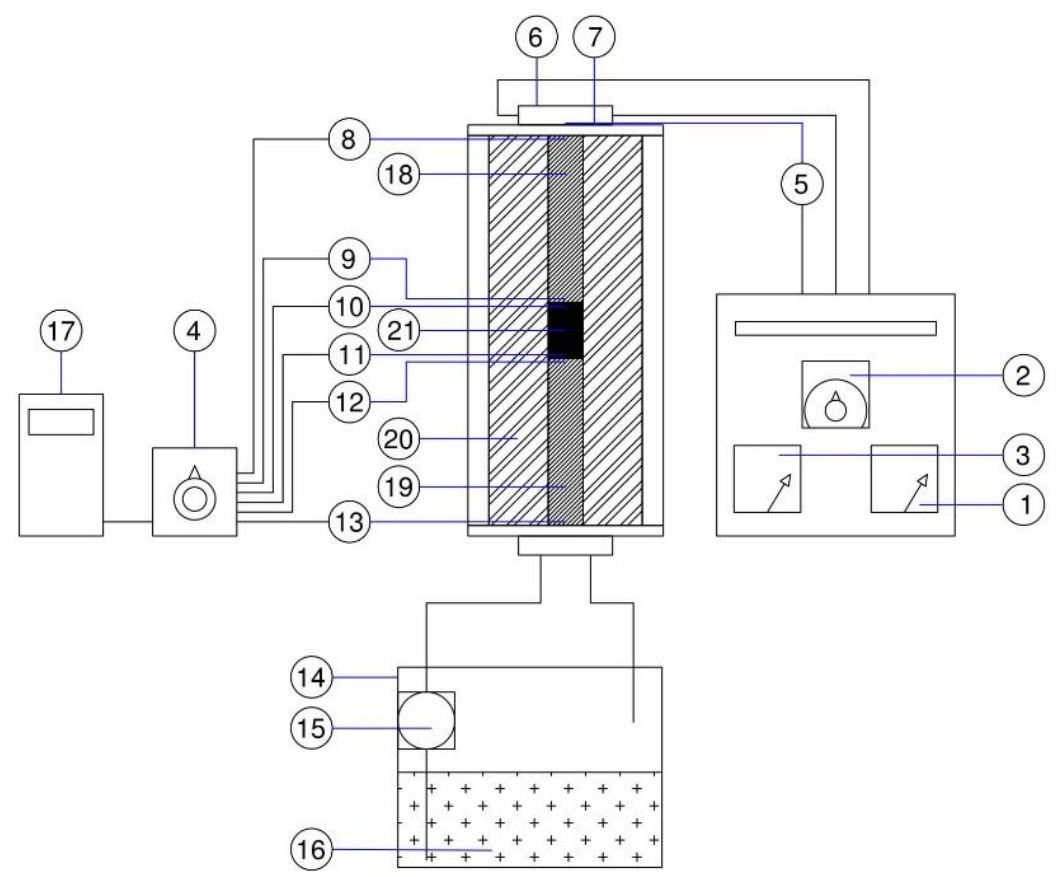

Figure. 2. Installation of Thermal Conductivity Test

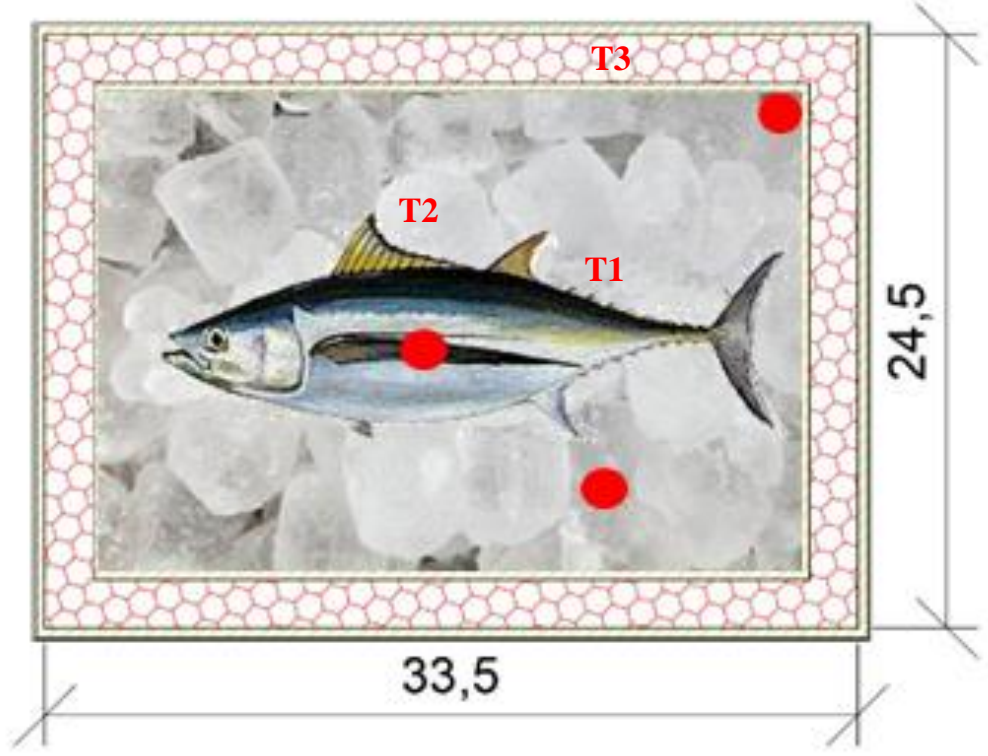

Figure. 3. Illustration of Coolbox from Top View

Annotation:

$\mathrm{T} 1=$ Ice Temperature in Coolbox

$\mathrm{T} 2=$ Fish Temperature in Coolbox

$\mathrm{T} 3=$ Temperature of Coolbox Chamber 
International Journal of Marine Engineering Innovation and Research, Vol. 4(2), Sept. 2019. 78-86 (pISSN: 2541-5972, eISSN: 2548-1479)

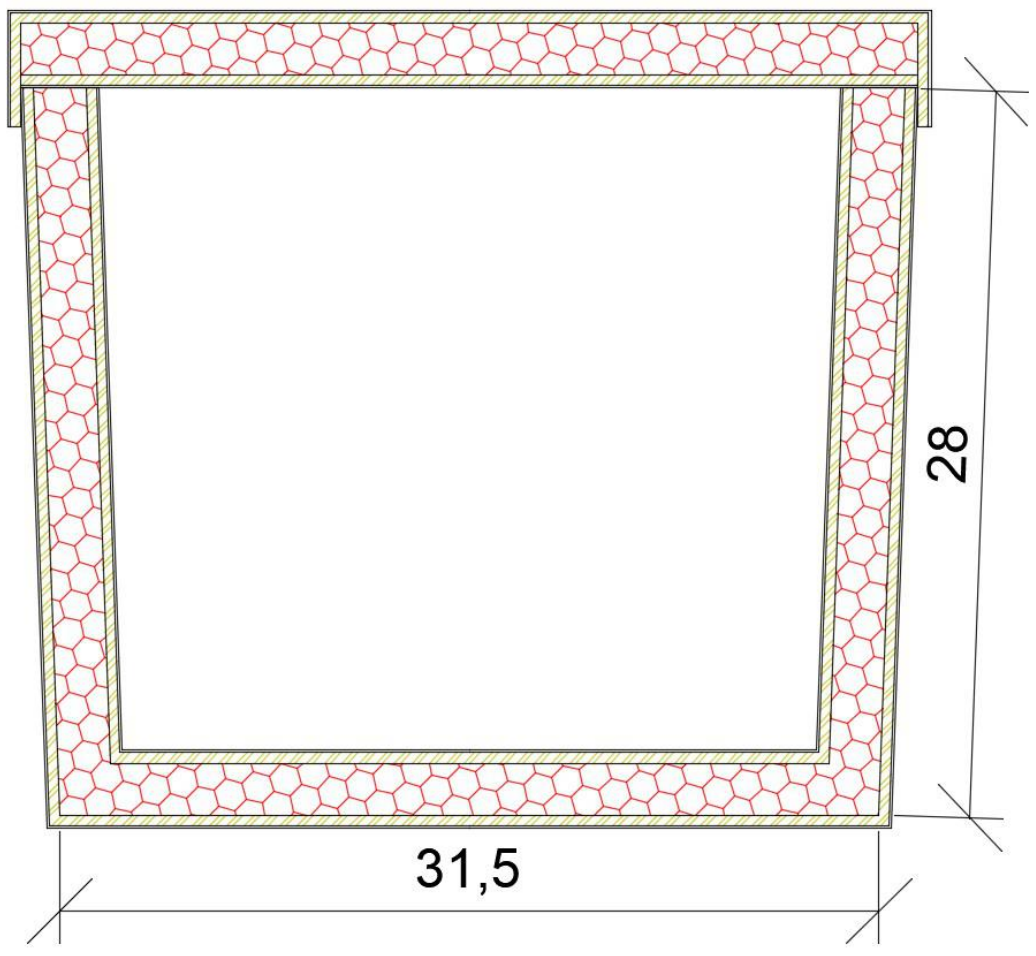

Figure. 4. Illustration of Coolbox from Side View

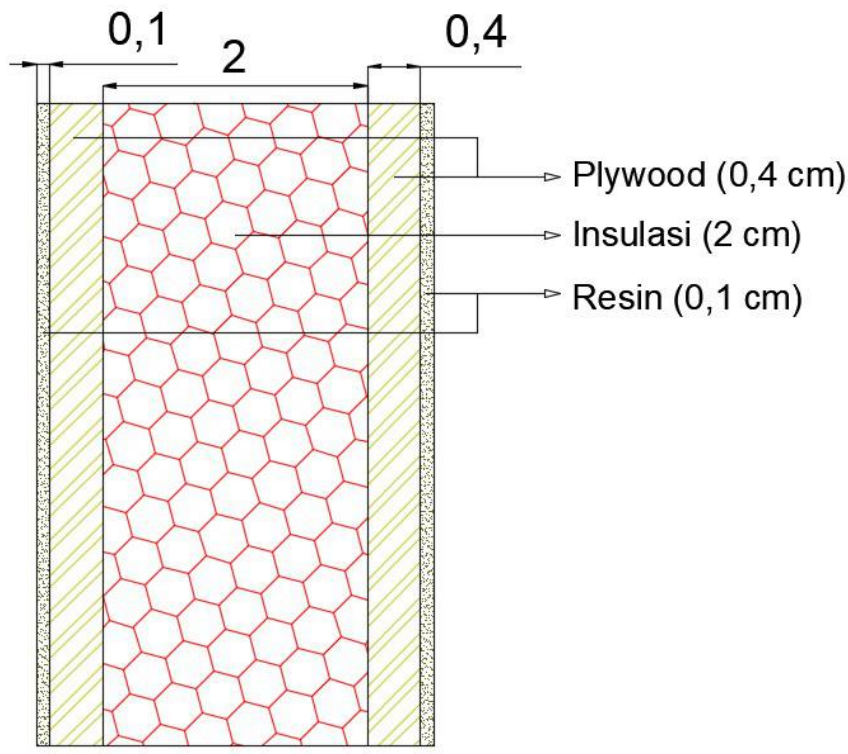

Figure. 5. Illustration of the insulation material layer in the coolbox
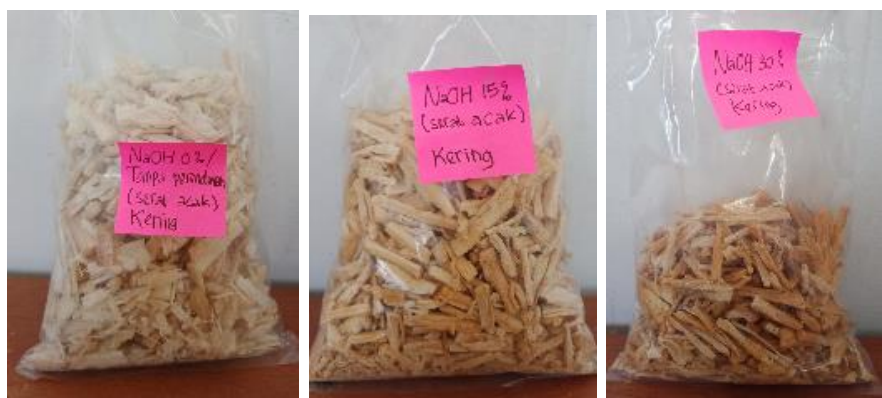

Figure. 6. Result of immersing fiber that has been dried 
TABLE 2.

COOLBOX SPECIFICATION

\begin{tabular}{cccc}
\hline \multirow{2}{*}{ Part } & \multicolumn{3}{c}{ Dimension } \\
\cline { 2 - 3 } & length $(\mathrm{m})$ & Width $(\mathrm{m})$ & Height $(\mathrm{m})$ \\
\hline Top & 33,5 & 24,5 & \multirow{2}{*}{28} \\
\hline Bottom & 31,5 & 22,5 & \\
\hline & \multicolumn{3}{c}{ Information } \\
\cline { 2 - 3 } & Teak Wood Sawdust & 50 & $\%$ \\
\cline { 2 - 3 } & Bagasse Fiber & 50 & $\%$ \\
\cline { 2 - 4 } Insulation & NaOH & 15 & $\%$ \\
\cline { 2 - 4 } & Density & 0,4901 & $\mathrm{~g} / \mathrm{cm}^{3}$ \\
\cline { 2 - 4 } & Polyurethane & 0,2171 & $\mathrm{~g} / \mathrm{cm}^{3}$ \\
\cline { 2 - 4 } & $\begin{array}{c}\text { Thermal } \\
\text { Conductivity }\end{array}$ & 0,2907 & $\mathrm{~W} / \mathrm{mK}$ \\
\cline { 2 - 4 } & Thick & 2 & $\mathrm{Cm}$ \\
\cline { 2 - 4 } & Volume & 8478,84 & $\mathrm{~cm}$ \\
\hline \multirow{2}{*}{ Layer } & Plywood & 4 & $\mathrm{Mm}$ \\
\cline { 2 - 4 } & Resin & 1 & $\mathrm{Cm}$ \\
\hline
\end{tabular}

TABLE 3.

DENSITY TEST RESULT

\begin{tabular}{|c|c|c|c|c|c|c|c|}
\hline \multirow{2}{*}{\multicolumn{2}{|c|}{$\begin{array}{l}\text { Random } \\
\text { Fiber }\end{array}$}} & \multicolumn{2}{|c|}{ Composition } & \multirow[b]{2}{*}{$\mathrm{NaOH}$} & \multirow[b]{2}{*}{$\begin{array}{c}\text { Mass } \\
\text { (gram) }\end{array}$} & \multirow[b]{2}{*}{$\begin{array}{c}\text { Volume } \\
(\mathrm{cm} 3)\end{array}$} & \multirow[b]{2}{*}{$\begin{array}{l}\text { Density } \\
(\mathrm{g} / \mathrm{cm} 3)\end{array}$} \\
\hline & & $\begin{array}{c}\text { Teak } \\
\text { Wood } \\
\text { Sawdust }\end{array}$ & Bagasse & & & & \\
\hline \multirow{9}{*}{ 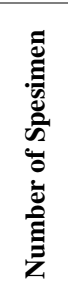 } & 1 & 70 & 30 & $0 \%$ & 30,9 & 54,97454 & 0,5620783 \\
\hline & 2 & 70 & 30 & $15 \%$ & 30,3 & 54,73738 & 0,5535523 \\
\hline & 3 & 70 & 30 & $30 \%$ & 30,2 & 54,71967 & 0,551904 \\
\hline & 4 & 50 & 50 & $0 \%$ & 29 & 57,95944 & 0,5003499 \\
\hline & 5 & 50 & 50 & $15 \%$ & 28,9 & 58,96631 & 0,4901104 \\
\hline & 6 & 50 & 50 & $30 \%$ & 28,7 & 58,79751 & 0,4881159 \\
\hline & 7 & 30 & 70 & $0 \%$ & 26,9 & 55,16636 & 0,487616 \\
\hline & 8 & 30 & 70 & $15 \%$ & 26,8 & 58,07402 & 0,4614801 \\
\hline & 9 & 30 & 70 & $30 \%$ & 26,3 & 58,13969 & 0,4523588 \\
\hline
\end{tabular}

TABLE 4.

THERMAL CONDUCTIVITY TEST RESULT

\begin{tabular}{|c|c|c|c|c|c|}
\hline \multirow[b]{2}{*}{ Specimen } & \multirow[b]{2}{*}{ Fiber } & \multicolumn{2}{|c|}{ Composition } & \multirow[b]{2}{*}{$\mathrm{NaOH}$} & \multirow{2}{*}{$\begin{array}{c}\text { Thermal } \\
\text { Conductivity } \\
\text { (W/mK) }\end{array}$} \\
\hline & & $\begin{array}{c}\text { Teak } \\
\text { Wood } \\
\text { Sawdust }\end{array}$ & Bagasse & & \\
\hline 1 & \multirow{9}{*}{ Random } & \multirow{3}{*}{70} & \multirow{3}{*}{30} & $0 \%$ & 0,7996 \\
\hline 2 & & & & $15 \%$ & 0,7225 \\
\hline 3 & & & & $30 \%$ & 0,7432 \\
\hline 4 & & \multirow{6}{*}{30} & \multirow{3}{*}{50} & $0 \%$ & 0,5813 \\
\hline 5 & & & & $15 \%$ & 0,2907 \\
\hline 6 & & & & $30 \%$ & 0,4069 \\
\hline 7 & & & & $0 \%$ & 0,6017 \\
\hline 8 & & & 70 & $15 \%$ & 0,4733 \\
\hline 9 & & & & $30 \%$ & 0,5096 \\
\hline
\end{tabular}

\section{c. Thermal Conductivity Test Result}

Based on table 4, For specimens with the composition of 50\% Teak Wood Sawdust and 50\% bagasse fiber, the thermal conductivity values range from $0.2907 \mathrm{~W} / \mathrm{mK}$ to $0.5813 \mathrm{~W} / \mathrm{mK}$ with the smallest average conductivity value of the specimens, which is $0.4263 \mathrm{~W} / \mathrm{mK}$.

Out of three variations of alkali $\mathrm{NaOH}$ treatment, specimens with variations in alkali $\mathrm{NaOH}$ treatment at $15 \%$ levels has the lowest average thermal conductivity value of $0.4955 \mathrm{~W} / \mathrm{mK}$. This is occurring due to the process of previously immersing fiber into an alkali solution $\mathrm{NaOH}$ gives rise to cellulose and eliminate impurities (lignin) on the surface of bagasse fiber which results in reduced diameter of the fiber. Thus, the process of immersing fiber into an alkali $\mathrm{NaOH}$ solution improves the mechanical properties of the fiber and reduces the value of thermal conductivity of the fiber material compared to those without the treatment of soaking the fiber into the alkali solution.

B. Specimen Selection

The selection of specimens is chosen by selecting which specimens are the most potential, both from a technical and economic perspective. 
TABLE 5.

SPECIMEN SELECTION

\begin{tabular}{|c|c|c|c|c|c|c|c|c|c|c|}
\hline \multicolumn{11}{|c|}{ IVIEN } \\
\hline \multirow{2}{*}{\multicolumn{2}{|c|}{$\begin{array}{c}\text { Random } \\
\text { Fiber }\end{array}$}} & \multicolumn{3}{|c|}{ Composition } & \multicolumn{4}{|c|}{ Score $(\%)$} & \multirow{2}{*}{$\begin{array}{c}\text { Total } \\
\text { Score } \\
(\%)\end{array}$} & \multirow[b]{2}{*}{ Rank } \\
\hline & & $\begin{array}{c}\text { Teak } \\
\text { Wood }\end{array}$ & Bagasse & $\mathrm{NaOH}$ & Thermal & Density & Production & Availability & & \\
\hline \multirow{9}{*}{ 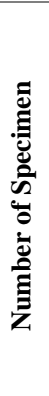 } & 1 & 70 & 30 & 0 & 6 & 2 & 19 & 3 & 30 & 9 \\
\hline & 2 & 70 & 30 & 15 & 17 & 4 & 17 & 10 & 48 & 7 \\
\hline & 3 & 70 & 30 & 30 & 11 & 7 & 8 & 9 & 35 & 8 \\
\hline & 4 & 50 & 50 & 0 & 28 & 9 & 22 & 2 & 61 & 5 \\
\hline & 5 & 50 & 50 & 15 & 50 & 11 & 14 & 8 & 83 & 1 \\
\hline & 6 & 50 & 50 & 30 & 44 & 13 & 6 & 7 & 70 & 3 \\
\hline & 7 & 30 & 70 & 0 & 22 & 16 & 25 & 1 & 64 & 4 \\
\hline & 8 & 30 & 70 & 15 & 39 & 18 & 11 & 6 & 74 & 2 \\
\hline & 9 & 30 & 70 & 30 & 33 & 20 & 3 & 4 & 60 & 6 \\
\hline
\end{tabular}

Based on table 5, the 5th specimen with a composition of $50 \%$ teak wood sawdust and $50 \%$ bagasse fiber with immersion treatment using alkali $\mathrm{NaOH} 15 \%$ has the first rank with a final percentage of $83 \%$.

\section{Coolbox Testing Result}

Testing of the preservation time is carried out until the fish reaches a temperature of $20^{\circ} \mathrm{C}$ while testing of changes in temperature of ice, fish, and Coolbox room is carried out for 24 hours.

Based on figure 7 , fish as a cooling load reaches a temperature of $20^{\circ} \mathrm{C}$ at different times for coolbox with random fiber variation, coolbox with straight fiber variation, and coolbox made of styrofoam. In the coolbox with random fiber variation, fish reaches temperatures of $20.2^{\circ} \mathrm{C}$ in a 1500th minute or in a duration of 25 hours. For coolbox with straight fiber variation, the fish reaches a temperature of $20.2^{\circ} \mathrm{C}$ in the 2040 minute or 34 hours. While in the coolbox made of Styrofoam, the fish reaches a temperature of $20^{\circ} \mathrm{C}$ in 2100 minute or 35 hours.
Based on figure 8 , at the first point or at the bottom of the surface of the ice, the coolbox with random fiber variation has the lowest temperature value of $0.1^{\circ} \mathrm{C}$ and reaches temperature value that is almost unchanged or relatively stable when it reaches temperatures of $0.3^{\circ} \mathrm{C}$ in $210^{\text {th }}$ to $690^{\text {th }}$ minute. While the coolbox with straight fiber variation has the lowest temperature value of $0.2^{\circ}$ $\mathrm{C}$ and reaches a relatively stable temperature value at a temperature of $0.3^{\circ} \mathrm{C}$ in the 210 th to $910^{\text {th }}$ minute.

Based on Figure 9, at the second point or on the body part of the fish, the coolbox with random fiber variation has the lowest temperature value of $6^{\circ} \mathrm{C}$ in 270th to 300th minute. For coolbox with straight fiber variation has the lowest temperature value of $5.8^{\circ} \mathrm{C}$ in 210 th to 270th minutes.

Based on Figure 9, the third point or inside the coolbox chamber for coolbox with straight fiber variation is capable of reaching the lowest temperature of $10.4^{\circ} \mathrm{C}$ with the fastest time duration compared to the other two coolboxes. However, along with increasing environmental temperature, the temperature of the coolbox also increases significantly.

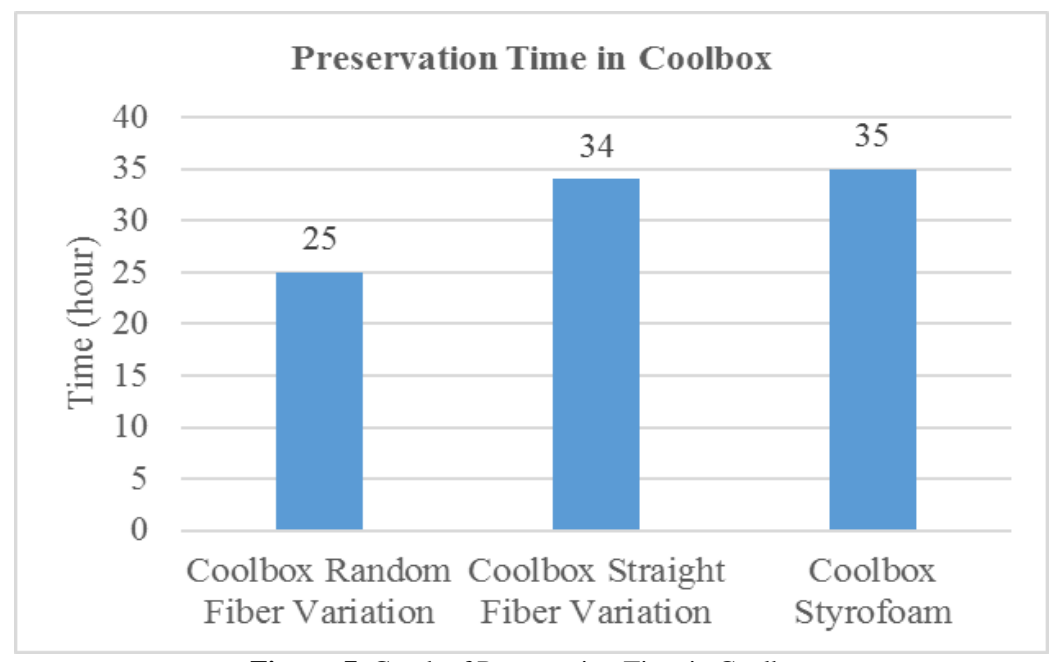

Figure. 7. Graph of Preservation Time in Coolbox 
International Journal of Marine Engineering Innovation and Research, Vol. 4(2), Sept. 2019. 78-86 (pISSN: 2541-5972, eISSN: 2548-1479)

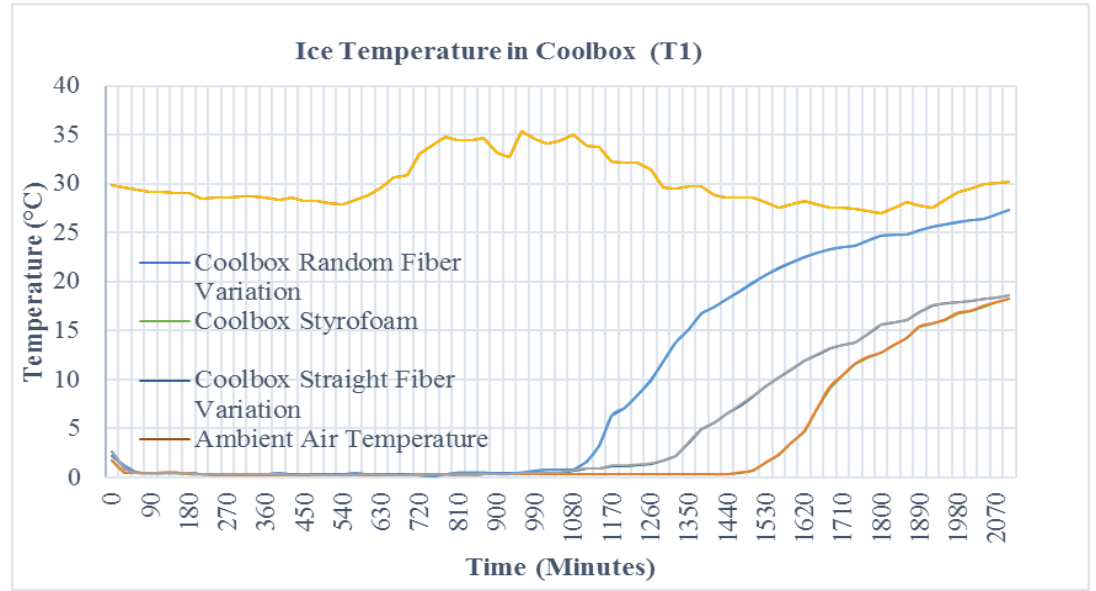

Figure. 8. Ice Temperature in Coolbox (T1)

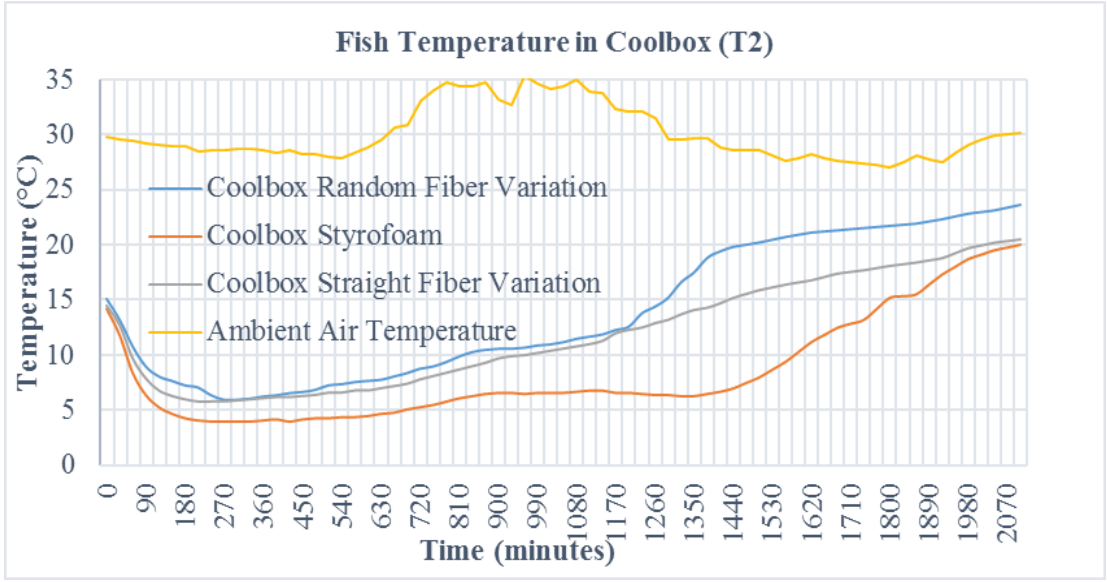

Figure. 9. Fish Temperature in Coolbox (T2)

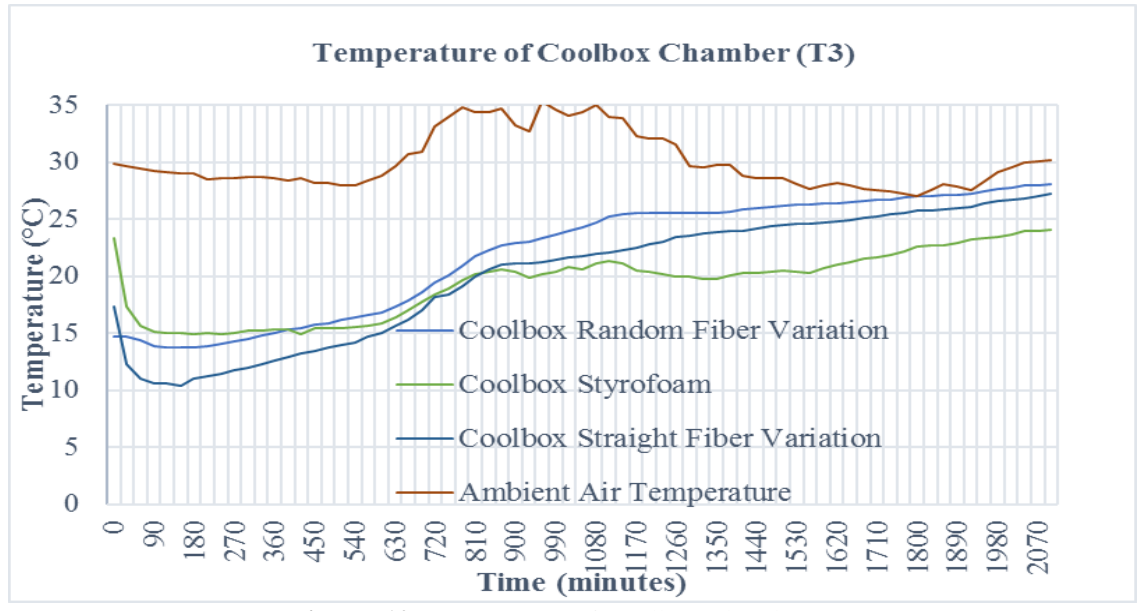

Figure. 10. Temperature of Coolbox Chamber (T3 


\section{CONCLUSION}

The fifth specimen insulation material with composition of $50 \%$ teak wood sawdust and $50 \%$ bagasse fiber treated with $15 \%$ alkali $\mathrm{NaOH}$ immersion has the most optimal value reviewed both technically and economically as a reference for making a coolbox. This specimen has the smallest conductivity value of $0.2907 \mathrm{~W} / \mathrm{mK}$ and has a density value of $0.4901 \mathrm{~g} / \mathrm{cm} 3$. For the duration of fishing for two days, coolbox with random fiber variation and coolbox with straight fiber variation have almost the same performance as Styrofoam and can be used as an alternative to Styrofoam coolboxes. Another advantage of coolbox with random fiber variation and straight fiber variation is applying materials from natural materials that are more environmentally friendly

\section{REFERENCES}

[1] Holman, J. 1994. Perpindahan Kalor (Edisi Keenam). Jakarta: Penerbit Erlangga.

[2] Ramadlan, dkk. 2013. Konduktivitas Panas pada Papan Partikel. Banda Aceh: Universitas Syiah Kuala

[3] Badrawada, I, G, Gde., Susilo, A. 2009. Pengaruh Kepadatan Papan Partikel dari Tiga Jenis Serbuk Kayu Terhadap Nilai Konduktivitas Panasnya.

[4] Maiwita, Fitri, dkk. 2014. Pengaruh Variasi Komposisi Ampas Tebu dan Serbuk Gergaji pada Papan Partikel Terhadap Konduktivitas Termal. Padang: Universitas Negeri Padang.

[5] Laksono, Pringgo Widyo Laksono, dkk. 2013. Desain dan Manufaktur Green-Composite Ampas Tebu Lem Putih sebagai Bahan Papan Partikel dan Berkarakteristik Hambat Panas. Surakarta: Universitas Negeri Sebelas Maret.

[6] Hidayat, M. 2017. Pemanfaatan Limbah Serbuk Kayu sebagai Campuran Polyurethane pada Insulasi Palka Kapal Ikan Tradisional, Surabaya: Jurusan Teknik Sistem Perkapalan FTK - ITS

[7] Abidin, M. .2017. Desain Sistem Pendingin Ruang Muat Kapal Ikan Tradisional Menggunakan Insulasi dari Sekam Padi. Surabaya: Institut Teknologi Sepuluh Nopember.

[8] Hidayat, M. N. 2017. Modifikasi Sistem Pendingin Ruang Muat Kapal Ikan Tradisional dengan Insulasi Serbuk Kayu dan Karung Goni. Surabaya : Institut Teknologi Sepuuh Nopember.

[9] Sihombing, Puteri Ladika. Desain Kotak Pendingin pada Kapal Nelayan Tradisional menggunakan Insulasi Campuran Serbuk Gergaji Kayu Sengon (Paraserianthes Falcataria (L.) Nielsen) dan Jerami: : Jurusan Teknik Sistem Perkapalan FTK - ITS.

[10] E. Akin D. 2008. Plant Cell Wall Aromatics: influence of degradation of biomass, biofuels,bioproducts, and bio process. Vol. 2 page $288-303$

[11] Anggorodi, R. 1994, "Ilmu Makanan Ternak". Jakarta: Gramedia Pustaka Utama.

[12] Albert L. Lehninger, David L. Nelson, dan Michael M. Cox. 2000. Lehninger Principles of Biochemistry. Worth Publishers, New York

[13] M. T. Holtz apple. 2003. Hemicelluloses. Encyclopedia of Food Sciences and Nutrition page 3060-3071

[14] O. Faruk, Andrzej K. Bledzki, Hans-Peter Fink, Mohini Sain. 2012. Biocomposites Reinforced with Natural Fibers. Progress in Polymer Science 37 page 1552-1596.

[15] Li X, Tabil LG, Panigrahi S, "Chemical Treatments of Natural Fibers for Use in Natural Fiber Reinforced Composites: a review". J Polym Environ. Vol. 15 (2007) 25-33

[16] Sultoni, Yusuf. Moh. Farid, Alvian T. Wibisono. 2017. Pengaruh Proses Alkali dan Fraksi Massa Serat terhadap
Sifat Fisik dan Sifat Mekanik Komposit Polyurethane/Coir Fiber. Surabaya: Institut Teknologi Sepuluh Nopember

[17] Ede M Wardhana, T Pitana, \& I Suryanto. (2016). Carbon Footprint Estimation for Pole and Line Fishing Vessel According to Its Operation Mode -Study Case at Papua Fisheries, Journal of Ocean, Mechanical and Aerospace Science and Engineering- 30, 2

[18] Alam Baheramsyah, Ede Mehta Wardhana, Muhammad Azis Husein (2018). Analysis of Palm Fiber and Coconut Coir Usage as Purse Seine Cargo Chamber Insulator. International Journal of Marine Engineering Innovation and Research - Volume 3 Issue 1 